\title{
AVIAN USE OF DESERT WILDLIFE WATER DEVELOPMENTS AS DETERMINED BY REMOTE VIDEOGRAPHY
}

\author{
Janet C. Lynn ${ }^{1,3}$, Steven S. Rosenstock ${ }^{2}$, and Carol L. Chambers ${ }^{1}$
}

\begin{abstract}
In the desert Southwest, migrating birds have been documented using upland habitat and xeroriparian washes as well as riparian areas. Yet aside from the river corridors, natural water sources (e.g., natural rock tanks [tinajas], springs, and ephemeral washes) in upland areas are scarce. Because of this scarcity, state and federal resource managers augmented water sources throughout the Southwest by constructing permanent wildlife water developments with the intention of enhancing game populations. However, despite these increases in free-standing water, there is a paucity of information on the use of water by birds during migration. Our objectives were to document use of these wildlife water developments by resident and migratory songbirds and assess the effectiveness of monitoring these species using remote color videography. We placed color video cameras at 2 wildlife water developments in southwestern Arizona during the spring and fall of 2004. Although we observed more use by migrants during spring than fall, overall use by migratory birds was low. However, the wildlife water developments were frequently used by resident birds. Remote videography provided continuous information on daily and seasonal patterns of bird use at wildlife water catchments with negligible disturbance by observers, yet for passerines, we felt that the benefits of remote videography did not justify the high cost of equipment purchase, installation, maintenance, and data processing.
\end{abstract}

Key words: Arizona, neotropical migratory birds, resident birds, Sonoran Desert, water developments, xeroriparian washes, video cameras.

In the desert Southwest, riparian areas are important stopover habitats for migrating birds (Johnson et al. 1977, Skagen et al. 1998, Kelly and Hutto 2005, Ecton et al. 2007); however, use of upland habitat and xeroriparian washes has also been documented (Kelly and Hutto 2005, Lynn et al. 2006). Yet aside from the river corridors, natural water sources (e.g., natural rock tanks [tinajas], springs, and ephemeral washes) in upland areas are scarce. Thus, stopover habitat that provides both food and water for migratory bird species beyond these corridors is limiting. Floodplains of the Colorado, Salt, and Gila rivers and their tributaries have been converted from native riparian vegetation to large-scale agricultural production and altered by water diversion and groundwater pumping for flood control, agricultural production, and community development (Sheridan and Nabhan 1978, Nabhan and Holdsworth 1999). These alterations have lowered water tables and decreased available freestanding water and riparian areas used by insectivorous migratory passerines (Johnson et al. 1977). Because naturally occurring desert waters are scarce, state and federal resource managers have augmented water sources throughout the Southwest by constructing permanent wildlife water developments with the intention of enhancing game populations (deVos and Clarkson 1990). As a result, >840 developed waters have been added in Arizona since the 1940s (Rosenstock et al. 1999). However, despite these increases in freestanding water, there is a paucity of information on the use of water by birds during migration (Cutler and Morrison 1998, O’Brien et al. 2006).

Previous studies that used imaging technology in the Southwest used triggered still cameras (Cutler and Swann 1999) and black-andwhite remote video cameras (O’Brien et al. 2006) to capture wildlife use of water developments, yet neither method was well suited for identifying small songbirds (e.g., the location and image quality did not permit reliable identification to species). Thus, our objectives were to document use of water developments by resident and migratory songbirds and assess the effectiveness of monitoring these species using remote color videography. Remote color

\footnotetext{
${ }^{1}$ Northern Arizona University, School of Forestry, Box 15018, Flagstaff, AZ 86011

2 Arizona Game and Fish Department, Research Branch, 2221 W. Greenway Road, Phoenix, AZ 85023.

${ }^{3}$ Present address: Ecological Monitoring and Assessment Program and Foundation, Box 5845, Flagstaff, AZ 86011. E-mail: janet.lynn@nau.edu
} 
TABLE 1. Birds recorded drinking from 2 wildlife water developments in southwestern Arizona, as determined by remote videography during spring (April-May) and fall (August-November) 2004. Recordings in spring were conducted for 60 days (864 hours) and in fall for 118 days (1517 hours).

\begin{tabular}{|c|c|c|c|}
\hline \multirow[b]{2}{*}{ Common name } & \multirow[b]{2}{*}{ Scientific name } & \multicolumn{2}{|c|}{ Number of individuals } \\
\hline & & $\overline{\text { Spring }}$ & Fall \\
\hline \multicolumn{4}{|l|}{ Migrants } \\
\hline Lazuli Bunting & Passerina amoena & 32 & 0 \\
\hline Yellow-rumped Warbler & Dendroica coronata & 5 & 4 \\
\hline Black-headed Grosbeak & Pheucticus melanocephalus & 3 & 4 \\
\hline Bullock's Oriole & Icterus bullockii & 3 & 0 \\
\hline Western Tanager & Piranga ludoviciana & 3 & 0 \\
\hline Western Kingbird & Tyrannus verticalis & 0 & 2 \\
\hline Unknown flycatcher & Empidonax sp. & 0 & 2 \\
\hline Brewer's Blackbird & Euphagus cyanocephalus & 0 & 1 \\
\hline TOTAL & & 46 & 13 \\
\hline \multicolumn{4}{|l|}{ Residents } \\
\hline Mourning Dove & Zenaida macroura & 2857 & 4673 \\
\hline House Finch & Carpodacus mexicanus & 6308 & 810 \\
\hline White-winged Dove & Zenaida asiatica & 3051 & 757 \\
\hline Gila Woodpecker & Melanerpes uropygialis & 491 & 704 \\
\hline Gambel's Quail & Callipepla gambelii & 165 & 281 \\
\hline Turkey Vulture & Cathartes aura & 369 & 88 \\
\hline Lesser Goldfinch & Carduelis psaltria & 0 & 385 \\
\hline Black-throated Sparrow & Amphispiza bilineata & 0 & 205 \\
\hline Common Raven & Geothlypis trichas & 119 & 15 \\
\hline Loggerhead Shrike & Lanius ludovicianus & 37 & 75 \\
\hline Say's Phoebe & Sayornis saya & 53 & 55 \\
\hline Ash-throated Flycatcher & Myiarchus cinerascens & 74 & 0 \\
\hline Scott's Oriole & Icterus parisorum & 35 & 0 \\
\hline Phainopepla & Phainopepla nitens & 24 & 0 \\
\hline Red-tailed Hawk & Buteo jamaicensis & 2 & 22 \\
\hline Brown-headed Cowbird & Molothrus ater & 4 & 11 \\
\hline American Kestrel & Falco sparverius & 0 & 8 \\
\hline Northern Mockingbird & Mimus polyglottos & 0 & 8 \\
\hline Great Horned Owl & Bubo virginianus & 1 & 4 \\
\hline Cactus Wren & Campylorhynchus brunneicapillus & 0 & 4 \\
\hline Elf Owl & Micrathene whitneyi & 4 & 0 \\
\hline Great-tailed Grackle & Quiscalus mexicanus & 4 & 0 \\
\hline Black-tailed Gnatcatcher & Polioptila melanura & 3 & 0 \\
\hline TOTAL & & 13,601 & 8105 \\
\hline \multicolumn{4}{|l|}{ Winter residents } \\
\hline Bewick's Wren & Thryomanes bewickii & 0 & 7 \\
\hline Cooper's Hawk & Accipiter cooperii & 0 & 7 \\
\hline White-crowned Sparrow & Zonotrichia leucophrys & 0 & 2 \\
\hline TOTAL & & 0 & 16 \\
\hline Unknown & & 89 & 2271 \\
\hline Unknown hummingbird & Trochilidae & 11 & 1 \\
\hline GRAND TOTAL & & 13,747 & 10,406 \\
\hline
\end{tabular}

videography was 1 of 5 methods used during a larger study on the use of wildlife water developments by birds in southwestern Arizona (Lynn et al. 2006).

We conducted our study in southwestern Arizona at 2 wildlife water developments during the spring and fall of 2004. Elevations for the sites were $547 \mathrm{~m}$ and $530 \mathrm{~m}$, and latitudes and longitudes were $33^{\circ} 14^{\prime} 51^{\prime \prime} \mathrm{N}, 114^{\circ} 17^{\prime} 50^{\prime \prime} \mathrm{W}$ and $33^{\circ} 18^{\prime} 46^{\prime \prime} \mathrm{N}, 114^{\circ} 18^{\prime} 46^{\prime \prime} \mathrm{W}$. The study area, classified as Sonoran desertscrub, Lower Colorado River subdivision (Turner and Brown 1982), was dominated by palo verde (Cercidium floridum and C. microphyllum), ironwood (Olneya tesota), creosotebush (Larrea tridentata), and brittlebush (Encilia farinose). During our study, 


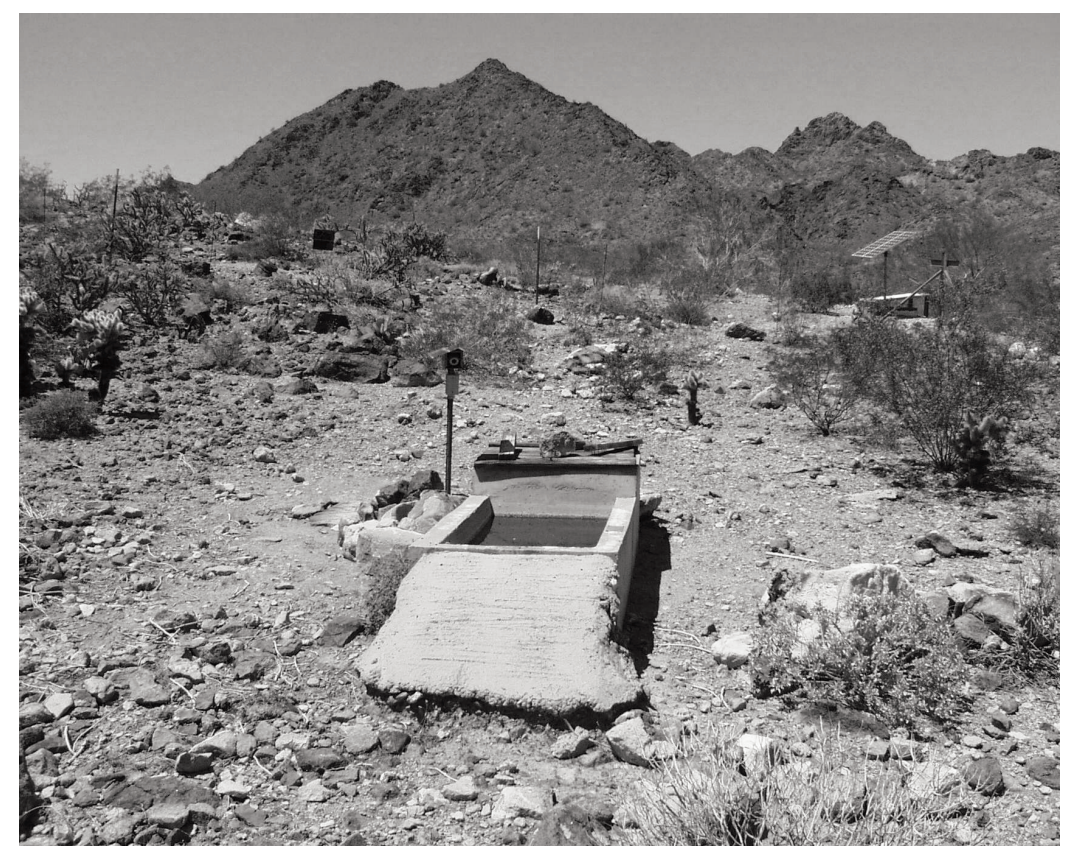

Fig. 1. Solar-powered color video cameras placed $1.5 \mathrm{~m}$ from the access ramp recorded bird use at a wildlife water development in southwestern Arizona.

temperatures ranged from $5.5^{\circ}$ to $38.8^{\circ} \mathrm{C}$ and winter precipitation (December-February) was $1.8 \mathrm{~cm}$ in 2003-2004 and $11.2 \mathrm{~cm}$ in fall (August-November) of 2004 (data available from: http://cdo.ncdc.noaa.gov/dly/DLY).

We selected water developments that were used in a previous remote videography study (O'Brien et al. 2006). Black-and-white videography documented hundreds of small passerines using these water developments; however, species were unidentifiable because of the proximity of cameras to the water catchment $(\leq 4 \mathrm{~m})$ and the lack of color video images. Direct observations of migratory birds foraging within the nearby xeroriparian washes also provided evidence of their presence at the site during spring and fall. The water developments we studied captured rainwater from corrugated metal apron catchment surfaces that drained into aboveground storage tanks and provided water via access ramps leading into an aboveground concrete trough (ca. $1 \times 1.5 \mathrm{~m}$ in size). All water developments were fully contained and did not supply water to surrounding vegetation. One water development was located within $30 \mathrm{~m}$ of a narrow (i.e., $50-100 \mathrm{~m}$ ) xeroriparian wash of scattered trees and shrubs abruptly bordered by desert upland. The 2nd was $300 \mathrm{~m}$ from a much wider (i.e., $500 \mathrm{~m}$ ), complex braided wash, but immediate surrounding vegetation was sparse.

We placed color video cameras (model \#CC02, Opticom Technologies, Ltd., Vancouver, $\mathrm{BC}$, Canada) $1.5 \mathrm{~m}$ from the edge of the access ramp at each trough, effectively capturing a $1 \times 1.5-\mathrm{m}$ area around the water surface and allowing a frontal view of birds on the ramp and a profile of birds perched on the side of the box (Fig. 1). Camera systems included solar panel arrays and a shaded belowground vault that housed 12-volt, 90-amp-hour, deep-cycle gel batteries, a charging system, a power supply, a VHS 168-hour time-lapse video recorder (model \#SVT168, Sony Corporation of America, New York), and associated electronics (O'Brien et al. 2006). Cameras began recording 1 hour before sunrise and continued until 1 hour after sunset for 5 consecutive days each week during spring migration (5 April-14 May) and for 4 consecutive days each week during fall migration (2 August- 18 November). Each VCR recorded 1 frame per second and videotapes were changed every 2 weeks. During video transcription, we recorded the species, frequency, and type (drinking, bathing) of use; time of day; and behavioral observations 
A

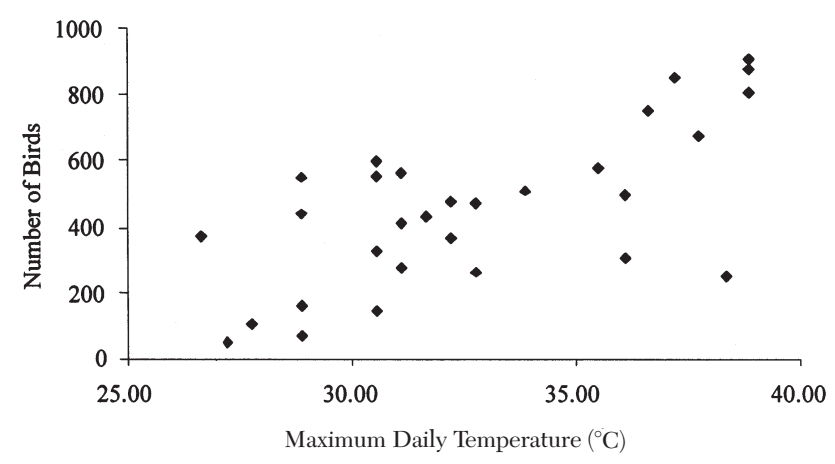

B

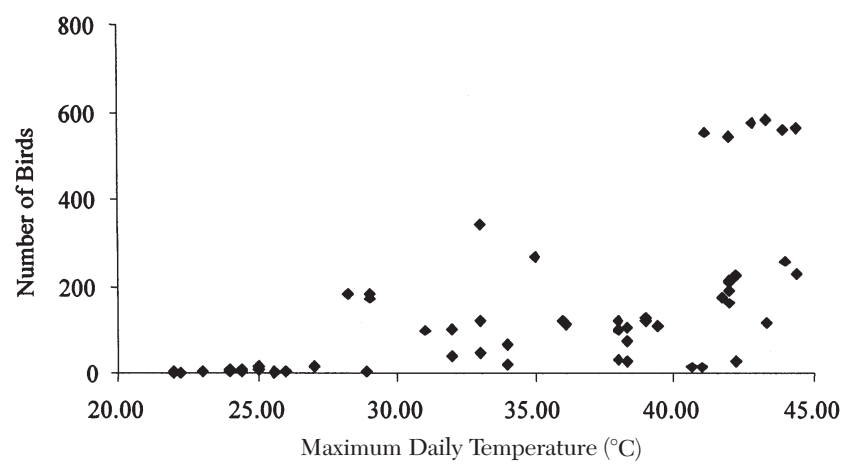

Fig. 2. Number of resident bird species recorded drinking at 2 wildlife water developments in southwestern Arizona, as determined by remote videography in spring 2004 (A) and fall 2004 (B).

such as inter- and intraspecific interactions. We obtained daily temperature data from the National Weather Service stations in Quartzite and at the U.S. Marine Corps Air Station, Arizona (data available from: http://cdo.ncdc.noaa .gov/dly/DYL). Migrants were defined as those species that did not breed within our study area, and winter residents were defined as those that overwintered within our study area but migrated north to breed (Corman and Wise-Gervais 2005). Bartholomew and Cade (1956) found a direct relationship between water consumption and ambient temperature in House Finches (Carpodacus mexicanus); therefore, we used linear regression to determine relationships between maximum daily temperatures and water use (Zar 1999).

During 2381 hours we recorded 24,153 birds using waters. We recorded higher numbers of individual migrants drinking at waters in spring $(n=46)$ than in fall $(n=13)$, despite greater observational effort in the fall (864 hours over 60 days in spring versus 1517 hours over 118 days in fall; Table 1). Species richness for migrants was equal for both seasons $(n=5)$. The Black-headed Grosbeak (Pheucticus melanocephalus) and the Yellow-rumped Warbler (Dendroica coronata) were the only migrant species recorded during spring and fall (Table 1). For residents, we recorded higher water use $(13,601$ versus 8105 visits) and species richness (19 versus 17 species) in spring (Table 1). Eleven resident species were recorded drinking during both seasons. Six species (Ash-throated Flycatcher, Scott's Oriole, Phainopepla, Greattailed Grackle, and Black-tailed Gnatcatcher) were recorded in spring but were not observed during fall.

Migrant use occurred during all but the hottest hours of the day (12:00-15:00). In contrast, visitation by resident species increased with increasing temperatures, and we found a 
positive relationship between visitation and maximum daily temperatures during spring $(r$ $=0.69, P<0.001)$ and fall $(r=0.61, P<0.001$; Fig. 2). However, birds may have been responding to other variables such as time of day; thus, this relationship should be interpreted with caution. With the start of winter rains, visitation by migrants and residents in October decreased dramatically from an average frequency of 160 visits during the first 2 weeks to an average of 6 visits during the last 2 weeks of the month.

Although we observed more use by migrants in spring than in fall, overall use by migratory birds of the 2 wildlife water developments in our study was low. The few migrant species that did visit and appeared to drink at water catchments have also been documented drinking in 2 previous studies at desert waters (Smyth and Coulombe 1971, Cutler and Morrison 1998). However, the wildlife water developments were frequently used by resident birds. Several residents such as Gambel's Quail (Callipepla gambelii), Gila Woodpecker (Melanerpes uropygialis), House Finch, Mourning Dove (Zenaida macroura), and White-winged Dove (Zeniada asiatica) used these waters throughout the year, while Lesser Goldfinch and Black-throated Sparrow visited waters more frequently in spring (Table 1).

The rate of water use by residents in spring was more than double the rate in fall $(15.9$ versus 6.9 individual visits per hour). Our spring 2004 data, collected during a drought year, differed from observations made during a wetter year by Lynn et al. (2006), who did not find a relationship between temperature and water use of resident species at nearby water catchments. The variation in seasonal water use may be in response to the change in diet and water content found in food resources (Bartholomew and Cade 1956) or the greater need for water during the breeding season.

Most notable was the high frequency of water use by the Black-throated Sparrow (Amphispiza bilineata). Although we did not record this species drinking in spring 2004, we observed 205 visits over 118 days of observation in fall 2004 (Table 1). The birds we observed appeared to drink and did not forage or bathe at waters. We recorded the highest frequency of water use $\left(\bar{x}=25\right.$ visits $\cdot$ day $\left.^{-1}\right)$ between 2 August and 16 August, when maximum daily temperatures ranged from $41^{\circ}-44^{\circ} \mathrm{C}$. Lower use was recorded during 11-20 October, when temperatures ranged from $28^{\circ}-35^{\circ} \mathrm{C}$. Although the Black-throated Sparrow is the only North American resident bird species known to survive without exogenous water (Smyth and Bartholomew 1966), Coe and Rotenberry (2003) demonstrated experimentally in a laboratory study that water availability affects reproduction in this species; pairs provided with supplemental water produced significantly larger clutches.

Remote videography provided continuous information on daily and seasonal patterns of bird use at wildlife water catchments with negligible disturbance by observers. Several species, such as the Turkey Vulture (Cathartes aura), Red-tailed Hawk (Buteo jamaicensis), Gambel's Quail, and Gila Woodpecker, were recorded drinking from catchments via remote videography, but they were not observed drinking or drank less frequently at catchments monitored by human observers (Lynn et al. 2006). Thus, some species may be more sensitive to disturbance, and remote videography may be more suitable than direct observation for these species. For passerines, we felt that the benefits of remote videography did not justify the high cost of equipment purchase, installation, maintenance, and data processing. Transcription of observations from videotapes was labor intensive, and identification of species was subject to difficulty because of image quality and camera resolution. For example, image quality during the midmorning and noon hours was poor because of glare both from the concrete of the water catchment and from the water surface. In fall 2004, we experienced technical difficulties that reduced image quality and made it difficult to distinguish migrants, such as the Lazuli Bunting (Passerina amoena) and several warbler species, from resident House Finches. This difficulty resulted in a larger percentage of unidentified birds in fall than in spring (23\% and $1 \%$, respectively). Video monitoring systems with higher resolution than we used could circumvent some of these problems.

\section{Literature Cited}

Bartholomew, G.A., and T.J. Cade. 1956. Water consumption of house finches. Condor 58:406-412.

Coe, S.J., And J.T. Rotenberry. 2003. Water availability affects clutch size in a desert sparrow. Ecology 84: 3240-3249.

Corman, T.E., And C. Wise-Gervais. 2005. Arizona breeding bird atlas. University of New Mexico Press, Albuquerque. 
Cutler, T.L., and M.L. MorRison. 1998. Habitat use by small vertebrates at two water developments in southwestern Arizona. Southwestern Naturalist 43:155-162.

Cutler, T.L., And D.E. Swann. 1999. Using remote photography in wildlife ecology: a review. Wildlife Society Bulletin 27:571-581.

DEVos, J.C., JR., And R.W. Clarkson. 1990. A historic review of Arizona's water developments with discussions on benefits to wildlife, water quality, and design considerations. Pages 157-165 in Proceedings of the Wildlife Water Development Symposium. Nevada Chapter of The Wildlife Society, USDI Bureau of Land Management, and Nevada Department of Wildlife. 30 November-1 December 1988, Las Vegas, NV.

Ecton, K.L., C. van Riper, III, T.C. Theimer, and E.H. PAXTON. 2007. Spatial and temporal migration patterns of Wilson's warbler (Wilsonia pusilla) in the southwest as revealed by stable isotopes. Auk 124: $162-175$.

Johnson, R.R., L.T. Haight, and J.M. Simpson. 1977. Endangered species vs. endangered habitats: a concept. Pages 68-79 in R.R. Johnson and D.A. Jones, editors, Importance, preservation, and management of riparian habitat. USDA Forest Service, General Technical Report RM-43, Washington, DC.

Kelly, J.F., And R.L. HutTo. 2005. An east-west comparison of migration in North American wood warblers. Condor 107:197-211.

Lynn, J.L., C.L. Chambers, and S.S. Rosenstock. 2006. Bird use of wildlife water developments in southwestern Arizona during spring migration. Wildlife Society Bulletin 34:592-601.
Nabhan, G.P., and A.R. Holdsworth. 1999. State of the biome: uniqueness, biodiversity, threats and the adequacy of protection in the Sonoran bioregion. The Wildlands Project, Tucson, AZ.

O’Brien, C.S., R.B. Waddell, S.S. Rosenstock, and M.J. RABE. 2006. Wildlife use of water catchments in southwestern Arizona. Wildlife Society Bulletin 34: $582-591$.

Rosenstock, S.S., W.B. BaLlaRd, and J.C. DEVos, JR. 1999. Benefits and impacts of wildlife water developments. Journal of Range Management 52:302-311.

Sheridan, T.E., AND G.P. Nabhan. 1978. Who killed the Gila? Pages 16-30 in Water in a thirsty land: Sonoran Desert and mountain river history. Piñon Press, Prescott, AZ. 90 pp. Reprinted from the Journal of Arizona History 19(1).

Skagen, S.K., C.P. Melcher, W.H. Howe, and F.L. Knopf. 1998. Comparative use of riparian corridors and oases by migrating birds in southeast Arizona. Conservation Biology 12:896-909.

Smyth, M., and G.A. Bartholomew. 1966. The water economy of the black-throated sparrow and the rock wren. Condor 68:447-458.

Smyth, M., AND H.N. Coulombe. 1971. Notes on the use of desert springs by birds in California. Condor 73: $240-243$.

Turner, R.M., AND D.E. Brown. 1982. Sonoran desertscrub. Desert Plants 4:181-221.

ZAR, J.H. 1999. Biostatistical analysis. 4th edition. Prentice Hall, Upper Saddle River, NJ.

Received 12 September 2006 Accepted 6 June 2007 